\title{
Regional government in Poland as a bodz shaping informational policy
}

\section{Pawel Kuca ${ }^{1}$ \\ Rafal Polak ${ }^{2}$}

\begin{abstract}
The present paper is aimed to analyze the activities of the regional government in Poland as an entity conducting activities in the field of information policy. This issue, apart from the theory related to the tasks of the regional government in Poland, is based on the results of the authors' research on the information policy conducted by the administrative units of the regional government in Poland. Two types of tests were used in the study. Primarily, the results of research on information policy conducted by the Marshal's Offices, which are organs of the local government administration, were used. These studies involved approach to communication activities in the regional government bodies, applied in organizational solutions, as well as the tools used in the field of information policy. The second part of the study concerned the issue of information policy at the level of regional councils, i.e. legislative bodies of regional governments in Poland.
\end{abstract}

Kez words: Local government, local administration, Poland, information policy, regional government

\section{INTRODUCTION}

The present paper is aimed to analyze how local government units in Poland at the regional level conduct information policy by means of media. The concept of information policy is understood here as planned, systematic and deliberate actions taken by representatives of local government. They are intended to allow local government units to communicate with residents (Chmielewski, Kuca, Polak 2015, p. 11).

The subject of conducted analysis seems to have a significant meaning. In the modern world public administration entities including local governments, which are similar to private companies, should give a high priority to a professional information policy. On the one hand, this allows to provide the residents of the communes and provinces with information on current events, on the other hand it also shapes the image of the local government in the opinion of the residents. It can influence the decisions taken by the citizens on the occasion of next election.

$1 \mathrm{PhD}$, University of Rzeszów, al. mjr. W. Kopisto 2a, 35-959 Rzeszów, Poland, Department of Political Science, e-mail pawel.kuca@ur.edu.pl.

$2 \mathrm{PhD}$, State Higher Vocational School in Krosno, Poland, Department of Management, Polytechnic Institute, e-mail r.polak@gazeta.pl. 
This seems important in the context of Stanislaw Michałowski's comments, who noted that criticism of the local government, lack of trust in the local authority may be due to errors in the conduct of information policy, or lack of such a policy (Michałowski 2006, p. 137).

The analysis was based on the authors' own research on the principles of information policy carried out by the local governments in Poland. The study also included a range of tools used in such activities.

\section{ELEMENTS OF THE GENESIS OF LOCAL GOVERNMENT ADMINISTRATION IN POLAND}

The genesis of local government in Poland should be sought in remote traditions of comitia minora (public assembly), which for hundreds of years expressed the opinion of the people from the provinces of the Republic of Poland about the central government plans. However, not looking back so far into the history, it must be recognized that contemporary Polish local government, or in broader terms, Polish public administration dates back to the Interwar period. At that time, the newly reborn Republic of Poland was striving for its identity after 123 years of non-existence on the map of Europe. One of the major challenges that the Polish authorities had to face was to build own local administration. Out of three existing administrative systems which sometimes differed substantially from each other in three partitions: Russian (division into governorates, districts and communes - lack of self-government of these units (Ajnenkiel 1977, p. 12)), Prussian (division into provinces, districts, rural and urban poviats, communes - self-government at the provincial, poviat and commune level (Izdebski 2001, pp. 51-52)) and the Austro-Hungarian (autonomy of the countries of the Crown, the greatest relative freedom of self-governments (Izdebski 2001, p. 52) and one common system of the reborn state was to be created. The main task that the newly formed Poland faced was to standardize the structure and system of different areas that were so far characterized by their distinctiveness. The introduction of the constitution which would regulate these issues was necessary. The March Constitution as it was popularly called was adopted on March 17, 1921 and stated that "The Republic of Poland based its system on the rule of, broad local government, and gave the representatives of local governments the right of legislation, especially in the field of administration, culture and keeping." (Art. 3. The Act dated 17 March 1921, The constitution of the Republic of Poland). The proposed broad local government was not implemented due to various reasons. After slings and arrows of outrageous fortune, structure of local government in Poland was finally inhibited by the outbreak of World War 
II, when the administration of the country was adjusted to the requirements of German and Russian administration.

Trying to identify the most important events concerning local government in the communist period, two main stages can be conventionally distinguished. The first one - 1944-1950 - the period immediately following World War II (e.g. elimination of traditional administrative organs and implementation of national councils) and the second one - 1950 to 1990 - national councils functioned in Poland instead of local government. Both in the first and the second period time limits, which are significant for self-government, can be determined (e.g. administrative reforms in 1972-1975 (Polak 2009)).

\subsection{Local administration in Poland and the political changes in 1989-1991}

The idea of self-government in Poland came back as a result of social changes connected with the change of the political system. These changes were initiated by Tadeusz Mazowiecki's government formed after the elections in June 1989. Parliamentary calls for local government which passed on 8 March 1990 with the Law on Local Government, which introduced local government in the country again. On the basis of this law the first elections to the newly created communes were held in May 1990.

The introduction in the near future of a three-stage administrative division was also announced, in which between the base unit - the commune and the province were poviats - representing an intermediate level. The announcement was confirmed by appropriate changes in the amended Constitution (the Act of July 22, 1952, which since December 1989 was called the Polish Constitution). Chapter IV of the constitution was renamed from "regional authorities and state administration" to "Local government". It was stated there that "local government is the basic form of public life organization in a commune." Shortly afterwards (October 17, 1992) "Constitutional Act on Mutual Relations between the Legislative and Executive authority of the Republic and local government" was passed which was called "Little Constitution". The role of local government in the state was highlighted there once again.

The first work on the poviats resulted in the creation so called "Map of the poviats" in 1993. Its creation was the result of many meetings and political consultations, but after the parliamentary elections in 1993 work on the new administrative division of the country was halted. They were started again after the 1997 election (Stec 1998, pp. 1-20). The new Constitution of the Republic of Poland was adopted in April 1997, Chapter VII was fully dedicated to local government. Article 164 paragraph 2 of the new stated that other units of local or 
regional government may arise by law (Art. 164, paragraph 2. Constitution of the Republic of Poland dated 2 April 1997, Journal of Laws 1997, No 78, paragraph 483)).

\subsection{Reform of Public administration in Poland in 1998/1999}

By virtue of this provision, the Sejm (Polish parliament) passed a number of laws on 5 June 1998, which became the basis of new territorial division. The Act on Local Government then changed its name to the Act on Commune Selfgovernment. The Act on Poviat Self-Government, Act on Regional Government and the Act on government administration in the province were also passed. All of these acts came into force on 1 January 1999 by introducing a new 3-level territorial division of Poland. As a result 16 provinces (Lower Silesia, KuyavianPomeranian, Lubelskie, Lubuskie, Łódzkie, Lesser Poland, Mazowieckie, Opolskie, Podkarpackie, Podlasie, Pomeranian, Silesian, Świętokrzyskie, Warmia and Mazury, Greater Poland, West Pomeranian), 314 poviats, 65 city poviats or towns/cities with poviat rights and 2,479 communes were established. The main objectives of the changes was to promote the development of civil society, improve the efficiency of public tasks, introduce transparency of administrative structures and the process of decision-making as well as the introduction of the ability to adapt administrative structures to changing external and internal conditions. The main principle accompanying these actions was the principle of subsidiarity and striving for decentralization of powers.

The subsidiarity in this sense means the introduction of the legal conditions to allow for a situation in which each level of local government performs only those tasks which cannot be (for various reasons) implemented by the lower level. Poland therefore joined the pan-European trend of political principles. It was considered that decision-making at lower levels of self-government means greater efficiency and effectiveness than it was if they were to be taken at the central level.

The advantages of decentralization corresponding to this principle (expressed in time in Art. 15 of the Polish Constitution) enumerated by theoreticians of Polish local government were as follows: close-up of the decisive entity to the case requiring action - this applies primarily to territorial decentralization, better ability to direct decision-making process in relation to the less complicated organizations, greater transparency leading to a better understanding of defects and their sources, increasing the potential introduction of new products (Izdebski, Kulesza 2004, pp. 123-125).

The Joint Commission of the Government and Local Government was 
established to make the process of reforms aimed to revolutionize the administrative system in Poland proceed correctly ${ }^{3}$. It is a forum for the elaboration of the common position of the Government and local government, which examines issues related to the functioning of local government as well as matters related to local government within the scope of action of the European Union and international organizations, which include the Republic of Poland. The Commission consists of representatives of the government and local authorities. The government side is represented by the minister responsible for public administration and 11 representatives appointed by the Prime Minister at his request. The self-government is represented by 2 persons out of the representatives of rural communes, rural-urban communes, town communes and communes in the cities over 300 thousand residents, as well as 2 representatives of national organizations representing the poviat and provincial government.

The main tasks of the Joint Commission of Government and Local Government (KWRIST) include: developing a common position of the Government and local government in the prioritization of economic and social matters concerning public utilities and the functioning of local government and district and regional development and functioning of the local government. The Commission shall also review and evaluate the legal and financial functioning of local government. It also analyzes prepared legal drafts, government documents and programs on local government and issues opinions on drafted legislation, programs and other government documents related to local government.

\subsection{General principles of the reform}

According to the definition by Hubert Izdebski and Michał Kulesza, public administration (broad objective-subjective scope) is a set of actions, activities and projects of organizational and executive character conducted for the public interest by different entities, bodies and institutions under the Act and in forms determined by particular legislation (Izdebski, Kulesza 2004, p. 93).

Monism or dualism could be distinguished in public administration depending on the system functioning in a given country. Monism of public administration means the existence of only state power - and understood that way it functioned in Poland in the years 1948-1990. In contrast, dualism of public administration has existed since 1990. Dualism was extended and well-grounded by changes introduced in 1998/1999.

3 Joint Commission of Government and Local Government was established by the Regulation of the Council of Ministers of 15 July 1997. Its mandate was clarified in a decree of 2002 and the Act of 6 May 2005 on the Joint Government and Local Government committee and the Polish representative in the EU Committee of the Regions (Journal of Laws of 2005 No. 90, item. 759). 
After the changes, which took place at that time, the public administration in Poland, can be divided into government administration and self-government administration. In the case of government, its representative in the field is a Voivod (governor). Self-government administration is local and regional (provincial), it is made up of collective and single person executive bodies appointed by the commune (poviat) council. A collegial body is a board, while the single person body is a Burgomaster (in rural and urban communes), the mayor (in cities with commune rights), or the poviat staroste (in commune). Collegial body at the regional level is the regional council, its executive body is a board headed by a Marshal of the province.

A commune is a basic level unit of local government (such provision appears in the Constitution), its authorities are elected during general elections. The exclusive competences of the commune council include: adopting the statute of a commune, appointing and dismissing the commune treasurer, adopting the commune budget, adopting local spatial development plans, passing economic programs, regulating of the scope of commune auxiliary units functioning, adopting resolutions on matters concerning property of the commune, determining the sum up to which the board can independently assume liabilities, taking resolutions on the adoption of the tasks entrusted to government administration, adopting resolutions on matters of cooperation with other communes, adopting resolutions on the coat of arms of the commune, names of streets, squares and monuments as well as giving the honorary citizenship of the commune (Izdebski 2001, pp. 141-142). The second level of local government is poviat which performs the tasks beyond commune level (e.g. in the field of combating unemployment, public order and safety, education at the secondary level, the protection of consumer rights, health and social assistance).

At the regional level is the province which has self-government - government character. Dualistic nature of public administration in the province requires a note here about the role of the Voivod, although the article focuses on the local administration. In case of government administration in the province, the Voivod is a representative of the Government. From this perspective his role is supervising the complex government administration (including the State Fire Service, Veterinary Inspection, Environmental Inspection, Trade Inspection). He also oversees the functioning of non-complex administration (customs, fiscal, military, statistical administration). 


\section{Picture 1: Public administration in Poland}

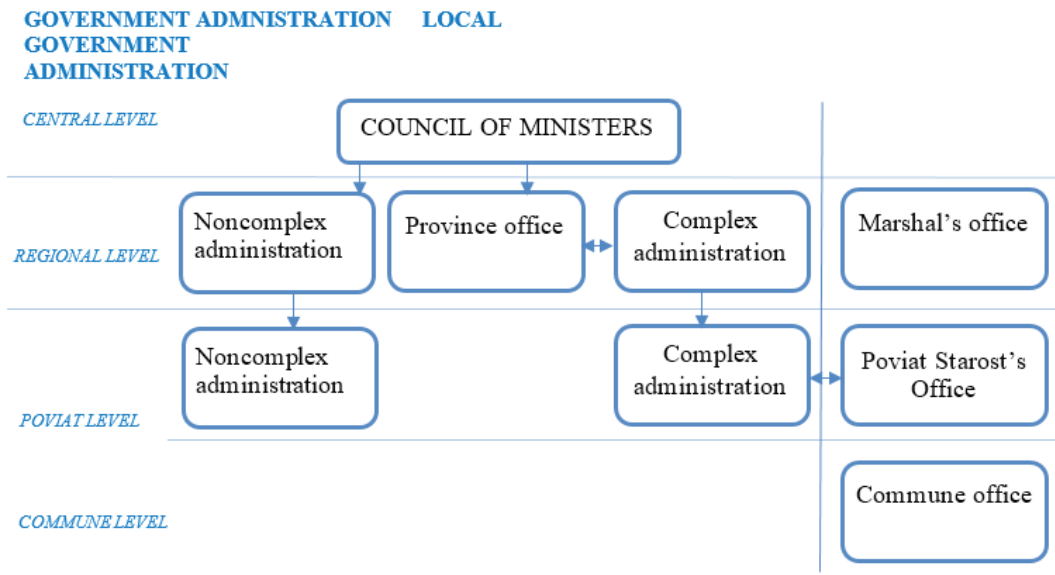

Source: Training materials of the Ministry of Administration and Digitisation of Poland.

According to the provisions of the Act on Self-Government at the Voivodship Level (Act on Self-Government at the Voivodship Level of 5 June 1998 (Journal of Laws dated 2014r. item 1072), the regional government runs a policy of the regional development, which consists of creating conditions for economic development, including the creation of the labor market, the maintenance and expansion of social and technical infrastructure significant for of the region, acquiring and joining financial resources: public and private, in order to carry out tasks related to public support and carry out activities to raise the level of education of citizens, the rational use of natural resources and shaping the environment, in accordance with the principle of sustainable development, supporting the development of science and cooperation between science and the economy, promoting technological progress and innovation, promoting the development of culture and care for the cultural heritage and its rational use, the promotion of values and development of opportunities in the region, supporting and carrying out activities for social inclusion and combating social exclusion. Local authority in the region consists of the legislative body (establishing law and controlling), which is the regional council and the executive body - the province government chaired by a Marshal. Its main tasks are: to perform the resolutions of the regional council, manage the property of the region including exercising the rights to shares owned by the province, preparing a draft and implementation 
of the budget of the region, preparation of a draft of a strategy for development of the region and other development strategies, spatial development plan, regional operational programs, programs for the partnership agreement in the field of cohesion policy and their performance, supervising, coordinating and controlling the activities of the local government units. In turn, the core competencies of the regional council include the fact that it is a legislative (adopting resolution) and controlling body, it elects the marshal and the board, adopts the statute of the region, adopts the budget of the region, adopts the strategy of development of the region and strategy documents, establishes international cooperation of the region, determines principles of provincial property management, determines the rules and procedures of the use of provincial buildings and public facilities.

\section{THE TASKS OF THE REGIONAL GOVERNMENT IN THE FIELD OF INFORMATION POLICY}

While carrying out its tasks the local government is obliged by law to provide information about its activities. This information is called "public information" within the meaning of the Act on access to public information (The act of 6 September 2001 on the access to public information (Journal of laws dated 2014 r. item 782) which is any information about public affairs, and as such shall be made accessible. Local government should share information both on its own initiative or at the request- as one of the institutions obliged to do $\mathrm{so}^{4}$. The basic information that should be made accessible are those relating to: legal status or legal form, the object of activities and competence, the bodies and persons exercising functions and their competences, the property and local government mode of action, the way of adopting and dealing with things as well as information about the registers, the records and archives and on the methods and principles of sharing the data contained therein.

The citizen looking for information about the activities of local government has the right to (The Act of 6 September 2001 on the access to public information, op. cit.) obtain public information, including information processed to the extent in which it is particularly important for the public interest; access to official

4 The Law on Access to Public Information indicates that Authorities are obliged to make public information public as well as other entities performing public tasks, in Particular: 1) organs of public authority; 2) self-government bodies and economic unions; 3) bodies representing the Treasury under separate regulations; 4) bodies representing state legal persons or legal entities of local government and other entities representing state entities or organizational units of local government; 5) bodies representing other persons or entities that perform public functions or have a public property, and legal persons in which the State Treasury, local government units or local economic or professional units have a dominant position within the meaning of the provisions on competition and consumer protection. 
documents; access to meetings of collective organs of public authority formed by universal elections. In order to implement this law smoothly, the above mentioned law obliged the authorities in Poland including the local government authorities to create the Public Information Bulletin (BIP) - a system of websites for broad and free access to public information. Under the law, it is mandatory that BIP publishes all the public information referred to in Art. 6 of the Act on access to public information with the exception of: the contents of administrative acts and other decisions and positions in public affairs taken by other public authorities and public officials.

\subsection{Marshal's Office as an organ of the local government administration}

The organs of public administration were constituted for the efficient execution of the tasks of local government, they were referred to in the act regulating their operation i.e. the Code of Administrative Proceeding (Art. 5. § 1. Of the act dated 14 June 1960r. the code of administrative proceeding (Journal of Laws 2013, position 267) as: ministers, central government bodies, provincial governors, other government bodies acting on their behalf or on their own behalf (complex and noncomplex), but also local government bodies and the bodies and entities which are established by law or under agreements to settle individual cases through administrative decisions. These bodies including the bodies of local government work by means of the auxiliary units. The Marshal's Offices are auxiliary units of local administration bodies at the regional level enabling them to carry out their tasks (including tasks resulting from the obligation to run the information policy).

The tasks of the Marshal include i.e.: ensuring conditions for local government authorities to implement their competences, providing conditions for the Marshal to perform tasks: Office manager, supervisor of official staff and heads of provincial self-government bodies, the chairman and organizer of the work of the board, the authority in individual cases in public administration, a representative of the province, ensuring the conditions for implementation of other tasks resulting from the law. The Office also provides substantive, legal, organizational, technical and office support for: the regional council, regional council committee, the chairman and vice-chairmen of the regional council, committee chairmen and councilors of the regional council, the board, the Marshal and the members of the board, treasurer, secretary.

The local government at the province level, as already mentioned, is obliged to provide information about its activities. On the one hand, it acts according to the provisions of the Act on access to public information, on the other hand the 
marshal's offices should pursue professional activities in the field of information policy, whereby the information on the activities of the local government will reach surroundings. The activities in the field of information policy can be conducted using a wide range of tools. One of the key elements here might be to use of the media as a part of media relations. The Marshal's Offices also appoint spokespersons (often working in cooperation with specialized units - press offices) to efficiently perform tasks in the field of information policy. The duties of a spoke person generally consist in a public representation of the activities of the marshal, the board or the regional council and documenting these activities. The following part of the paper presents the results of research in the way of conducting information policy by means of media by the marshals' offices in Poland as well as the scope of information policy application by these agencies in the context of relations with the media.

\section{RESEARCH METHODOLOGY}

The research presented in the paper were conducted in two stages - each was based on anonymous questionnaires completed by respondents. The first research was conducted in the period from October to November 2014. It concerned the approach to information policy in the regional government in Poland. The questionnaire included questions about the approach to information policy in the Marshall's Offices, the organization of information policy, tools used in the field of information policy and the frequency of their use. The survey was sent to all 16 Marshals' offices in Poland. Replies from 12 offices were obtained (basic version of this part of the research was published in: Chmielewski, Kuca, Polak 2015.

The second part of the research concerned the principles of information policy in the offices of the regional councils. The study was conducted in 2015, it should be treated as an opportunity to obtain more detailed information on information policy in the regional councils. Tests were also carried out on the basis of anonymous questionnaires sent to regional council offices. The responses from 12 offices (out of 16 provinces in Poland) were obtained.

Due to the small number of regional governments, research results were presented in numbers, not percentages.

\subsection{Research results}

The analysis shows that the representatives of the regional governments in Poland are aware that the communication activities of public institutions are an 
important element in conducting purposeful relationship with the media. The representatives of all 12 marshal's offices, who took part in the study, agreed with such statement. The respondents emphasized that currently it is quite difficult to imagine the effective communication of public institutions without a purposeful relationship with the media, and the media can be an effective channel to pass important information about public institutions to residents. In addition, conducting relations with the media is important because it can affect the perception of the institution by the citizens and create the image of the institution. Thus, the representatives of all 12 Marshal's offices, who participated in the survey declared that their institutions conduct targeted media relations. However, various organizational solutions for the media relations policy (several solutions could be indicated in the questionnaire) are introduced in the different regional governments. In each of 12 Marshal's offices there is an organizational unit which is responsible for contacts with the media. However, the spokesperson is in 10 Marshal's offices. A special department or other entity is responsible for contact with the media in 7 offices. Three tested Marshal's offices have organizational unit in charge of media relations, but these tasks are only a part of its responsibilities. The number of staff in the organizational units, which are designed to conduct contacts with the media, is quite varied. They employ from 1 up to 6 people. It is worth noting that one employee in the organizational unit who implements media policy in the Marshal's office (except spokesperson) occurred only in one region.

Besides the differences in staffing, a different division of competences on the conduct of media policy is present in particular Marshal's offices. Among the researched Marshal's offices, where in six offices people in the media policy unit are responsible only for media relations of the province government. Also, in six Marshal's offices, a press department conducts information policy of both the province government and the regional council. Research on the regional council showed that out of 12 local governments that participated in this part of the study, only three regional council offices have a separate budget for information policy.

Interesting information is provided in answers to questions about the traditional and customized communication tools that are used in the Marshal's offices in charge of conducting information policy.

In the category of traditional tools, representatives of regional governments in Poland use fairly wide range of tools in their information actions. Popular tools of information policy used in the Marshal's offices are press conferences, press releases distributed to journalists (e.g. via e-mail), as well as meetings with journalists on the occasion of various events (all of these tools have been used in each of 12 Marshal's offices which participated in the study). When it 
comes to press conferences at the level of regional council, chairman of the regional council, regional council presidium or councilors - in 5 regions they have conferences independent of the board of the province.

Popular tools of information policy also include individual contacts with journalists, as well as inviting journalists to variety of events (11 responses). Not all of the tested provinces decide to publish their own magazines. They operate in nine Marshal's offices. On the other hand, in seven offices the information is communicated by means of a newsletter.

Table 1: Traditional communication tools used in the marshal's offices in charge of information policy.

\begin{tabular}{|l|c|}
\hline \begin{tabular}{l}
$\mid \begin{array}{l}\text { What traditional communication tools are used in your regional unit in } \\
\text { charge of information policy? }\end{array}$ \\
\hline Individual contacts with journalists
\end{tabular} 11 \\
\hline Press conferences & $\mathbf{1 2}$ \\
\hline Information sent by mail to journalists (fax, e-mail) - urgently & $\mathbf{1 2}$ \\
\hline Newsletter or other form of systematic electronic transmission & $\mathbf{7}$ \\
\hline Inviting journalists at events (various) & $\mathbf{1 1}$ \\
\hline Meeting with journalists on the occasion of various events & $\mathbf{1 2}$ \\
\hline Own periodical publication (a magazine) & $\mathbf{9}$ \\
\hline
\end{tabular}

Source: Chmielewski, Kuca, Polak 2015, p. 112.

When it comes to modern and customized communication tools that are used in informative actions, it should be noted that all marshal's offices involved in the study had an official required by law website. However, not all of them have an extra website or web portal. Such tool was used by 10 offices. The survey conducted among the representatives of the regional council showed that most councils do not have own separate website ( 9 responses of the representatives of the regional council). Most commonly, the legislative body of the regional government has a separate subpage or tab on the website of the local government or the marshal's office. Three regions have a separate web page of the regional council.

It is worth noting that 10 Marshals' offices in the researched group use social media for the purpose of information policy and have a profile or fun-page on Facebook (two regions have their profiles on other social networking sites). Only 4 out of 12 researched Marshal's offices provide information about their activities using Twitter. It is worth noting that residents of 7 regions can watch 
the sessions of the regional council on-line.

Table 2: Modern and customized communication tools used in the Marshal's offices for communicative activities.

\begin{tabular}{|l|c|}
\hline \multicolumn{2}{|l|}{$\begin{array}{l}\text { What trWhich new / modern / customized communication tools are used } \\
\text { in your regional unit to conduct information policy? }\end{array}$} \\
\hline Official required by law website & $\mathbf{1 2}$ \\
\hline $\begin{array}{l}\text { Official extra website or information web portal of Marshal's } \\
\text { office }\end{array}$ & $\mathbf{1 0}$ \\
\hline Facebook profile or fan page & $\mathbf{1 0}$ \\
\hline Twitter profile or fan page & $\mathbf{4}$ \\
\hline Profile or fan page on other social media portal & $\mathbf{2}$ \\
\hline On-line transmission of regional council sessions & $\mathbf{7}$ \\
\hline Blog of a member of a province government & - \\
\hline Blog of a selected Marshal's offices employee & - \\
\hline
\end{tabular}

Source: Chmielewski, Kuca, Polak 2015, p. 116.

In addition to the catalogue of information, policy tools that are available to the officials responsible for communication at the Marshal's offices, the frequency of using each instrument is also important. As for the traditional tools of information policy, fairly broad catalog of tools is used every day in the studied marshal's offices. This includes information sent to journalists ( 8 responses), a newsletter (5 responses), as well as individual contacts with journalists (4 responses). One Marshal's Office organizes press conferences daily.

Five traditional tools of information policy are used in the Marshal's offices once a week. These include individual contacts with journalists and press conferences (3 responses), newsletter and inviting journalists to a variety of events (2 responses), meeting with journalists on the occasion of various events (1 responses).

In some Marshal's Offices, the same information policy tools are used less often, that is several times a week. This applies to individual contacts with selected journalists and press conferences ( 3 offices), as well as sending information to journalists, inviting journalists to the events (4 responses).

It can also be observed that when it comes to publishing own magazines, marshal's offices usually opt for monthly magazines (5 responses), or quarterlies (4 responses). Detailed date are presented in table 3. 
Table 3: Frequency of use of traditional communication tools in information policy of marshal's offices.

\begin{tabular}{|l|c|c|c|c|c|c|}
\hline \multicolumn{1}{|c|}{ Tool } & Daily & $\begin{array}{c}\text { Once a } \\
\text { week }\end{array}$ & $\begin{array}{c}\text { A few } \\
\text { times a } \\
\text { week }\end{array}$ & $\begin{array}{c}\text { Once a } \\
\text { month }\end{array}$ & $\begin{array}{c}\text { A few } \\
\text { times a } \\
\text { month }\end{array}$ & $\begin{array}{c}\text { Once a } \\
\text { quarter } \\
\text { or less } \\
\text { often }\end{array}$ \\
\hline $\begin{array}{l}\text { Individual contacts } \\
\text { with selected jour- } \\
\text { nalists }\end{array}$ & 4 & 3 & 3 & - & 1 & - \\
\hline Press conferences & 1 & 3 & 3 & 2 & 3 & - \\
\hline $\begin{array}{l}\text { Information sent by } \\
\text { mail to journalists } \\
\text { fax, e-mail) }\end{array}$ & 8 & - & 4 & - & - & - \\
\hline $\begin{array}{l}\text { Newsletter or other } \\
\text { form of systematic } \\
\text { electronic transmi- } \\
\text { ssion }\end{array}$ & 5 & 2 & - & - & - & - \\
\hline $\begin{array}{l}\text { Inviting journalists } \\
\text { at events (various) }\end{array}$ & 3 & 2 & 4 & 1 & 1 & - \\
\hline $\begin{array}{l}\text { Meeting with } \\
\text { journalists on the } \\
\text { occasion of various } \\
\text { events }\end{array}$ & 1 & 1 & 5 & - & 3 & 1 \\
\hline $\begin{array}{l}\text { Own periodical } \\
\text { publication (maga- } \\
\text { zine) }\end{array}$ & - & - & - & 5 & - & 4 \\
\hline
\end{tabular}

Source: Chmielewski, Kuca, Polak 2015, p. 113.

Analyzing the frequency of use of modern communication policy tools, it should be noted that the marshal's offices use them very often. Most of the tools available to the regional governments are used in informative actions every day. Most of the surveyed offices act that way.

Websites are most commonly used tools among those that are used daily. The Public Information Bulletin (11 responses) was used as frequently as additional web page or a web portal run by the Marshal's Office (10 responses). Social media are popular and frequently used. Facebook is used daily for information 
policy in 9 regional governments and Twitter in 4 marshal's offices.

When it comes to on-line transmission of regional council sessions, they are used monthly - the frequency of council sessions. Out of seven regional governments, which use this tool, 6 governments used them once a month, while once a quarter or less often.

Detailed data is presented in Table 4.

Table 4: Frequency of use of modern / customized communication tools in information policy of marshal's offices.

\begin{tabular}{|l|c|c|c|c|c|c|}
\hline \multicolumn{1}{|c|}{ Tool } & Daily & $\begin{array}{c}\text { Once a } \\
\text { week }\end{array}$ & $\begin{array}{c}\text { A few } \\
\text { times a } \\
\text { week }\end{array}$ & $\begin{array}{c}\text { Once a } \\
\text { month }\end{array}$ & $\begin{array}{c}\text { A few } \\
\text { times a } \\
\text { month }\end{array}$ & $\begin{array}{c}\text { Once a } \\
\text { quarter } \\
\text { or less } \\
\text { often }\end{array}$ \\
\hline $\begin{array}{l}\text { Individual contacts } \\
\text { with selected jour- } \\
\text { nalists }\end{array}$ & 4 & 3 & 3 & - & 1 & - \\
\hline Press conferences & 1 & 3 & 3 & 2 & 3 & - \\
\hline $\begin{array}{l}\text { Information sent by } \\
\text { mail to journalists } \\
\text { (fax, e-mail) }\end{array}$ & 8 & - & 4 & - & - & - \\
\hline $\begin{array}{l}\text { Newsletter or other } \\
\text { form of systematic } \\
\text { electronic transmi- } \\
\text { ssion }\end{array}$ & 5 & 2 & - & - & - & - \\
\hline $\begin{array}{l}\text { Inviting journalists } \\
\text { at events (various) }\end{array}$ & 3 & 2 & 4 & 1 & 1 & - \\
\hline $\begin{array}{l}\text { Meeting with } \\
\text { journalists on the } \\
\text { occasion of various } \\
\text { events }\end{array}$ & 1 & 1 & 5 & - & 3 & 1 \\
\hline $\begin{array}{l}\text { Own periodical } \\
\text { publication (maga- } \\
\text { zine) }\end{array}$ & - & - & - & 5 & - & 4 \\
\hline
\end{tabular}

Source: Chmielewski, Kuca, Polak 2015, p. 117. 


\section{CONCLUSION}

In summary, several conclusions can be drawn from the above analysis. On the one hand, representatives of the regional governments in Poland are aware of the fact of how important it is to carry out communicative activities, which include also correctly realized contacts with the media. Individual regions apply different organizational solutions in this matter, which address both the scope of competence of individual organizational units responsible for media relations, as well as staffing. Differences in approach to information policy, however, are seen in the analysis of tools used in communication activities. Analysis of the traditional tools of information policy revealed that regional governments apply a wide range of communications tools. They are also used regularly.

Slightly different conclusions can be drawn in the context of the communication tools determined in the paper as a modern and customized. The range of such communication tools in the regional governments is almost as wide as the range of traditional tools. However, they are limited largely to websites and profiles of local governments in social networking. A higher level of creativity could be postulated when it comes to customized tools of information policy in the regional government in Poland.

\section{REFERENCES}

AJNENKIEL A. (1977), Administracja w Polsce, Warszawa.

CHMIELEWSKI Z., KUCA P., POLAK R. (2015), Public relations i polityka informacyjna w samorzadzie terytorialnym, Rzeszów.

IZDEBSKI H., KULESZA M. (2004), Administracja publiczna. Zagadnienia ogólne, Warszawa.

IZDEBSKI H. (2001), Samorząd terytorialny. Podstawy ustroju i działalności, Warszawa.

MICHAŁOWSKI S. (2006), Polityka informacyjna $w$ samorzadzie terytorialnym a społeczeństwo obywatelskie [in] Władza lokalna a media. Zarzadzanie informacja - public relations - promocja jednostek samorzadu terytorialnego, red. S. Michałowski, W. Mich, Lublin.

POLAK R. (2009), Demokracja lokalna. Między prasa a władza, Rzeszów.

STEC M. (1998), Ustrój terytorialny administracji publicznej w Polsce, w: „Reforma administracji publicznej”, z. 2, Warszawa.

\section{ACTS OF LAW}

THE ACT DATED 17 MARCH 1921, The constitution of the Republic of 


\section{Poland.}

CONSTITUTION OF THE REPUBLIC OF POLAND dated 2 April 1997, (Journal of Laws 1997, No 78, paragraph 483).

ACT ON SELF-GOVERNMENT AT THE VOIVODSHIP LEVEL of 5 June 1998 (Journal of Laws dated 2014r. item 1072).

THE ACT OF 6 SEPTEMBER 2001 On the access to public information (Journal of laws dated 2014 item 782).

ART. 5. § 1. OF THE ACT DATED 14 JUNE 1960r. The code of administrative proceeding (Journal of Laws 2013. position 267). 